\title{
EVALUASI KEGIATAN PENGENALAN TEKNIK BUDIDAYA BAWANG MERAH DI DESA BATU AMPAR KECAMATAN MERIGI KABUPATEN KEPAHIANG PROVINSI BENGKULU
}

\section{EVALUATION OF SHALLOT CULTIVATION INTRODUCTION IN BATU AMPAR VILLAGE, MERIGI DISTRICT, KEPAHIANG DISTRICT, BENGKULU PROVINCE}

\author{
Nyayu Neti Arianti ${ }^{1)^{*}}$, Mimi Sutrawati ${ }^{2)}$, Marlin $^{3)}$ \\ ${ }^{1)}$ Program Studi Agribisnis Fakultas Pertanian, Universitas Bengkulu \\ email: nnarianti@unib.ac.id \\ ${ }^{2)}$ Program Proteksi Tanaman Fakultas Pertanian, Universitas Bengkulu \\ ${ }^{3)}$ Program Studi Agroekoteknologi Fakultas Pertanian, Universitas Bengkulu
}

\begin{abstract}
ABSTRAK
Bawang merah merupakan salah satu komoditas hortikultura strategis dan bernilai ekonomi tinggi. Ketersediaan bawang merah dipengaruhi oleh luas lahan budidaya dan kendala organisme pengganggu tanaman. Saat ini Kementerian Pertanian menetapkan perluasan daerah budidaya bawang merah di berbagai daerah di Indonesia, salah satunya adalah Kabupaten Rejang Lebong dan Kabupaten Kepahiang di Provinsi Bengkulu. Petani membutuhkan informasi teknik budidaya yang tepat. Kegiatan ini dilakukan bertujuan untuk memperkenalkan teknik budidaya bawang merah dan kemudian dilanjutkan dengan melakukan evaluasi sehingga diperoleh persepsi petani tentang budidaya bawang merah yang diperkenalkan. Petani antusias mengikuti kegiatan penyuluhan serta pengamatan di lapangan, Hasil evaluasi kegiatan menunjukkan bahwa sebagian besar petani memberikan persepsi yang baik terhadap teknologi budidaya bawang merah yang diperkenalkan.
\end{abstract}

Kata kunci: Bawang Merah, Pengenalan, Budidaya, Evaluasi

\section{ABSTRACT}

Shallots are one of the strategic horticultural commodities and have high economic value. The availability of shallots is influenced by the area of cultivated land and the constraints of plant-disturbing organisms. At present the Ministry of Agriculture is establishing expansion of shallot cultivation areas in various regions in Indonesia, one of which is Rejang Lebong Regency and Kepahiang Regency in Bengkulu Province. Farmers need information on proper cultivation techniques. This activity was carried out aiming to introduce the technique of shallot cultivation and then proceed with an evaluation to obtain farmers' perceptions about the cultivation of shallots that were introduced. Farmers were enthusiastic in participating in the extension activities as well as observations in the field. The results of the evaluation showed that most farmers gave a good perception of the shallot cultivation technology introduced.

Keywords: Shallot, Introducing, Farming, Evaluation

PENDAHULUAN

Bawang merah merupakan salah satu komoditas hortikultura yang strategis karena memiliki nilai ekonomis tinggi.
Bawang merah dibutuhkan dalam kehidupan sehari-hari namun ketersediaan bawang merah masih belum mencukupi kebutuhan dengan distribusi ketersediaan 
bawang merah yang tidak merata sepanjang tahun.

Balai Penelitian Tanaman Sayuran (Balitsa) sejak tahun 1984-2012 telah melepas atau mendaftarkan 11 varietas bawang merah yang cocok ditanam di dataran rendah sampai dataran tinggi. Varietas bawang merah dataran rendah yang juga cocok ditanam di dataran tinggi yaitu varietas Sembrani, Pikatan, Trisula, Pancasona dan Mentes. varietas yang cocok ditanam di luar musim atau pada musim hujan (off-season) yaitu varietas Trisula dan Sembrani. Pada tahun 2014 Balitsa juga telah mengajukan pendaftaran 2 (dua) calon varietas bawang merah True Shallot Seed (TSS).

Peningkatan minat masyarakat untuk membudidayakan bawang merah harus selalu digalakkan mengingat potensi bawang merah yang memiliki nilai ekonomi tinggi sehingga dapat menjadi sumber pendapatan masyarakat [1]. Penanaman bawang merah harus dilakukan pada provinsi lain selain sentra produksi bawang merah di Indonesia, yakni Jawa Tengah, Jawa Timur, Jawa Barat dan Nusa Tenggara Barat untuk memenuhi permintaan bawang merah nasional yang selalu meningkat. Penyebaran lokasi sumber produksi bawang merah harus dilakukan. Provinsi Bengkulu juga ditetapkan sebagai wilayah pengembangan komoditi bawang melalui Keputusan Menteri Pertanian RI. Untuk itu telah ditetapkan Kabupaten Rejang Lebong menjadi salah satu kawasan pengembangan bawang merah di Provinsi Bengkulu. Program pengembangan tanaman bawang dan bawang putih di Provinsi Bengkulu dilakukan di Kabupaten Rejang Lebong [2].

Terdapat empat kecamatan yang menjadi lokasi pengembangan, yakni Kecamatan Bermani Ulu, Bermani Ulu Raya, Selupu Rejang dan Kecamatan Sindang Kelingi. Kecamatan Merigi dimana Desa Batu Ampar berlokasi belum menjadi sasaran pengembangan komoditi bawang merah. Namun pada tahun 2020 dan 2021 Kecamatan Merigi direncanakan juga menjadi salah satu sentra pengembangan komoditi bawang merah Kabupaten Kepahiang. Bantuan disalurkan melalui kelompok tani. Setiap kelompok tani itu nantinya mendapatkan jatah bibit bawang yang akan dikembangkan di atas lahan seluas dua hektar.

Minat petani untuk menanam bawang merah cukup besar. Namun, teknik budidaya bawang merah belum sepenuhnya dikuasai petani, terutama dalam menghadapi serangan organisme pengganggu tanaman (OPT). Penguasaan teknologi tepat guna budidaya bawang merah akan sangat bermanfaat dalam upaya meningkatkan produktivitas bawang merah [1].

Adanya serangan hama dan penyakit pada bawang merah ini menjadi ancaman serius bagi para petani karena dapat menyebabkan kehilangan hasil panen. 
Masalah utama dalam budidaya bawang merah adalah serangan hama ulat bawang (Spodoptera exigua). Hama ini merupakan hama utama di sentra produksi bawang merah. Kehilangan hasil panen akibat serangan ulat bawang dapat mencapai $100 \%$ jika tidak dilakukan upaya pengendalian karena hama ini bersifat polifag [3]. Selain itu beberapa penyakit juga sering menyerang atnaman bawang merah, seperti penyakit moler atau layu (Fusarium oxysporum), penyakit antraknos (Coletotrichum gloesporioides), dan penyakit trotol (Altemaria porri). Pengetahuan tentang OPT sangat penting diberikan pada petani sehingga mereka dapat melakukan antisipasi dan pengendalian terhadap serangan OPT pada bawang merah.

Tujuan kegiatan pengabdian kepada masyarakat ini adalah untuk: 1) Memperkenalkan atau memberikan pengetahuan pada petani tentang teknik budidaya bawang merah, dan 2) Mengetahui sejauh mana penilaian petani peserta terhadap teknologi budidaya tanaman bawang yang dikenalkan.

\section{METODE PELAKSANAAN KEGIATAN}

Kegiatan pengabdian ini meliputi kegiatan pengenalan teknik budidaya tanaman bawang di lahan, serta evaluasi kegiatan. Kegiatan pengenalan teknik budidaya bawang merah dilakukan dengan cara memberikan penyuluhan serta mengikutsertakan para peserta secara aktif dalam kegiatan. Sasaran kegiatan adalah para petani di Desa Batu Ampar Kecamatan Merigi Kabupaten Rejang Lebong yang merupakan anggota kelompok tani. Para petani ini diharapkan setelah mengikuti kegiatan memiliki pengetahuan tentang teknik budidaya bawang merah. Dengan demikian petani memiliki gambaran dan bekal pengetahuan jika program pengembangan budidaya bawang merah dilaksanakan di Desa Batu Ampar.

Teknik pengumpulan data untuk menggali persepsi petani peserta terhadap teknologi budidaya bawang merah dilakukan dengan cara wawancara menggunakan kuesioner yang sudah dipersiapkan.

Aspek-aspek yang dievaluasi adalah aspek kemudahan mengakses input dan peralatan budidaya, aspek kemudahan teknik budidaya, aspek keuntungan ekonomi, aspek kesesuaian dengan kondisi sosial, budaya dan lingkungan, serta aspek keinginan petani untuk mengadopsi teknologi budidaya bawang merah. Selain masing-masing aspek, dievaluasi pula persepsi, pendapat atau penilaian petani terhadap keseluruhan aspek. Pertanyaanpertanyaan yang diberikan memiliki alternatif jawaban seperti pada Tabel 1. 
Tabel 1. Alternatif dan skor jawaban

\begin{tabular}{clc}
\hline No. & \multicolumn{1}{c}{ Alternatif Jawaban } & Skor \\
\hline 1. & S (Sangat Setuju) & 2 \\
2. & S (Setuju) & 1 \\
3. & R (Ragu-ragu) & 0 \\
4. & TS (Tidak Setuju) & -1 \\
5. & STS (Sangat Tidak Setuju) & -2 \\
\hline
\end{tabular}

Selanjutnya skor jawaban petani pada masing-masing aspek. Total skor pada masing-masing aspek ini kemudian dibandingkan dengan skor rata-rata seluruh petani. Untuk persepsi petani terhadap budidaya bawang merah secara keseluruhan dilakukan dengan cara menjumlahkan skor semua aspek dan selanjutnya juga dibandingkan dengan rata-rata total skor semua aspek.

Tabel 2. Kategori persepsi, pendapat atau penilaian petani

\begin{tabular}{|c|c|c|}
\hline No. & $\begin{array}{c}\text { Dasar } \\
\text { Pengkategorian }\end{array}$ & Kategori \\
\hline 1. & $\begin{array}{l}\text { Total skor } \\
\text { petani } \geq \text { rata- } \\
\text { rata total skor } \\
\text { seluruh petani }\end{array}$ & $\begin{array}{c}\text { Mudah/ } \\
\text { Menguntungkan/ } \\
\text { Sesuai/Ingin/Baik }\end{array}$ \\
\hline 2. & $\begin{array}{l}\text { Total skor } \\
\text { petani < rata- } \\
\text { rata total skor } \\
\text { seluruh petani }\end{array}$ & $\begin{array}{l}\text { Tidak Mudah/ } \\
\text { Kurang } \\
\text { Menguntungkan/ } \\
\text { Kurang } \\
\text { Sesuai/Tidak } \\
\text { Ingin/Kurang } \\
\text { Baik }\end{array}$ \\
\hline
\end{tabular}

\section{HASIL DAN PEMBAHASAN}

1. Kegiatan Pengenalan Teknik Budidaya Bawang Merah

Kegiatan dilakukan dengan teknik penyuluhan yang dilakukan dengan memberikan materi tentang teknik budidaya bawang merah. Kegiatan penyuluhan dilakukan dengan cara memberikan ceramah dan tanya jawab terhadap anggota kelompok tani yang hadir dalam kegiatan. Setelah diberikan materi penyuluhan maka dilanjutkan dengan kegiatan diskusi dengan cara peserta diberikan kesempatan untuk memberikan tanggapan terhadap materi yang telah disampaikan yaitu berupa pertanyaan atau pendapat kepada tim penyuluh. Selanjutnya tim penyuluh langsung memberikan ulasan/pembahasan terhadap pertanyaan atau pendapat yang diajukan peserta.

Kegiatan selanjutnya adalah kunjungan ke lahan budidaya bawang merah. Dalam kegiatan ini dilakukan antara lain memperlihatkan aplikasi teknik budidaya bawang merah di lapangan. Kegiatan lain adalah memperkenalkan cara mengidentifikasi dan investigasi langsung hama penyakit yang menyerang bawang merah. Kegiatan ini juga dilanjutkan dengan kegiatan diskusi dan tanya jawab yang berkaitan dengan temuan hama dan penyakit yang ditemukan.

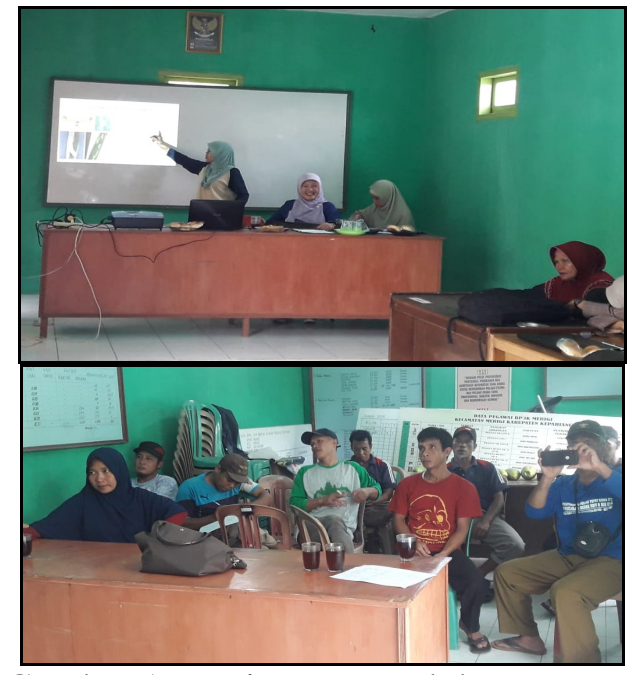

Gambar 1. Kegiatan penyuluhan tentang pengenalan teknik budidaya bawang merah 


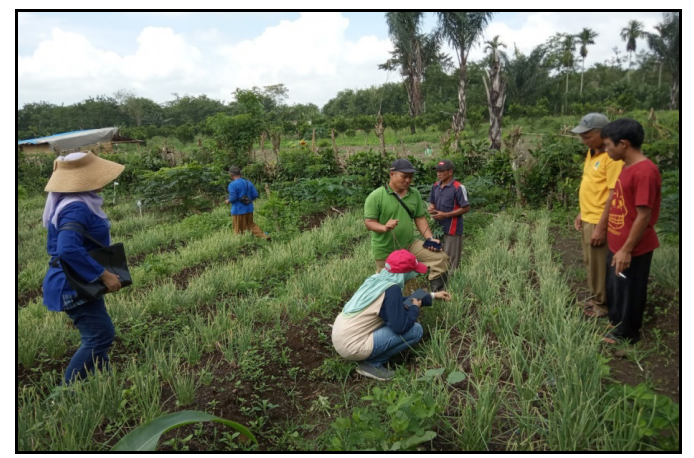

Gambar 2. Investigasi hama dan penyakit yang menyerang bawang merah di lahan

2. Evaluasi kegiatan pengenalan teknik budidaya bawang merah

Evaluasi terhadap kegiatan PPM yang telah dilakukan bertujuan untuk mengetahui persepsi petani peserta kegiatan tentang pengenalterapan teknik budidaya bawang merah.

Persepsi atau penilaian petani peserta meliputi aspek kemudahan mengakses input dan peralatan budidaya, aspek kemudahan teknik budidaya, aspek keuntungan ekonomi, aspek kesesuaian dengan kondisi sosial, budaya dan lingkungan, serta aspek kesediaan petani untuk mengadopsi teknologi budidaya tanaman bawang merah.

Hasil evaluasi dijabarkan berdasarkan masing-masing aspek maupun secara total atau keseluruhan aspek, sebagai berikut :

a). Aspek kemudahan memperoleh input dan peralatan budidaya

Input dan peralatan produksi merupakan persyaratan pokok dalam suatu kegiatan budidaya pertanian. Kemudahan mengakses input berupa lahan, tenaga kerja, bibit atau benih, pupuk, serta pestisida menjadi pertimbangan petani dalam memulai kegiatan budidaya atau usahatani.
Hasil evaluasi menunjukkan bahwa sebagian besar petani peserta memberikan persepsi atau penilaian yang baik terhadap kemudahan mengakses input dan peralatan produksi bawang merah (56\%), sementara $44 \%$ memberikan persepsi kurang baik (Gambar 3).

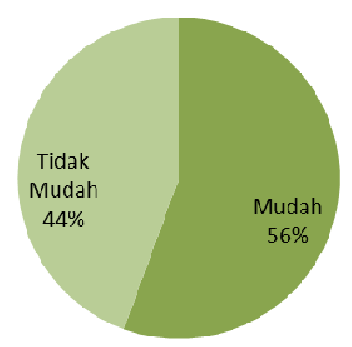

Gambar 3. Penilaian petani tentang kemudahan memperoleh input dan peralatan budidaya

Hal ini disebabkan oleh petani peserta adalah petani yang memiliki lahan sendiri $(77,78 \%)$ dan sudah terbiasa melakukan kegiatan pertanian karena menjadi mata pencaharian pokok. Input dan peralatan budidaya bawang merah umumnya relatif sama dengan budidaya komoditi lainnya, seperti tenaga kerja, pupuk, dan pestisida. Input-input produksi relatif mudah diperoleh di Desa Batu Ampar, karena lokasi desa ini dekat dengan pusat Kota Curup yang menjadi ibukota Kabupaten Rejang Lebong serta ketersediaan sarana dan prasarana transportasi yang sangat memadai.

Petani umumnya memberikan pernyataan penilaian yang kurang baik pada akses memperoleh bibit bawang merah, karena belum diketahui darimana dapat memperoleh bibit bawang merah dengan 
jumlah dan kualitas yang baik. Selama ini petani di Kabupaten Selupu Rejang menanam bawang merah lokal yang memiliki kemampuan produksi yang rendah.

b). Aspek kemudahan teknik budidaya

Teknik budidaya bawang merah meliputi tahapan : pemilihan bibit, pengolahan lahan, penanaman, penyiraman, penyulaman, pemupukan, pengendalian organisme pengganggu tanaman (OPT), pemanenan dan pasca panen. Sebagian besar petani (56\%) menyatakan teknik budidaya tanaman bawang merah dapat dilakukan dengan mudah.

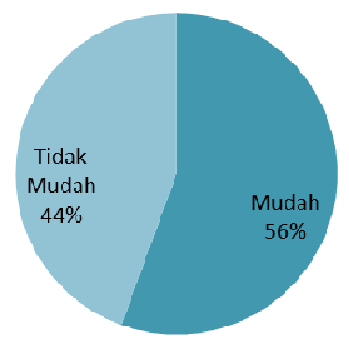

Gambar 4. Penilaian petani tentang kemudahan teknik budidaya

Tahapan-tahapan kegiatan budidaya bawang merah sama dengan teknik budidaya tanaman semusim lainnya. Umur tanaman bawang merah yang singkat (5570 hari) juga menjadi pertimbangan petani menilai budidaya bawang merah lebih mudah dilakukan. Hal umumnya yang dinilai petani tidak mudah untuk dilakukan adalah pengenalan dan pengendalian Organisme Penganggu Tanaman (OPT), karena tanaman ini baru diperkenalkan.

c). Aspek keuntungan ekonomi

Aspek yang tidak kalah penting dalam memperkenalkan suatu teknologi baru adalah seberapa jauh teknologi itu memberikan manfaat ekonomi. Pertimbangan untung rugi tentu menjadi dasar untuk mengadopsi suatu teknologi baru. Dalam kegiatan ini, aspek ekonomi yang dinilai oleh petani adalah ketersediaan modal yang dimiliki, harga input produksi, harga output, pemasaran, prospeknya dalam menciptakan pendapatan, prospeknya dalam menciptakan lapangan kerja baru serta kelayakannya untuk dikembangkan di masa mendatang.

\section{Gambar 5. Persepsi petani tentang keuntungan ekonomi}

Sebagian besar petani (56\%) menyatakan budidaya tanaman bawang merah akan memberikan manfaat-manfaat secara ekonomi. Permintaan bawang merah yang terus meningkat menjadikan harga bawang merah akan meningkat, sehingga usahatani bawang merah sangat prospektif untuk dikembangkan.

Keuntungan atau tingkat pendapatan yang diperoleh secara kongkrit akan memberikan semangat dalam berusaha. Indikator yang yang dapat digunakan untuk mengintroduksikan suatu inovasi atau teknologi baru adalah keuntungan ekonomis, biaya dan permodalan, resiko 
yang lebih rendah, hemat tenaga dan waktu dan imbalan segera diperoleh, membutuhkan biaya yang terjangkau oleh kemampuan finansial petani dan produksinya mempunyai prospek pasar yang baik [4].

Namun sebanyak $44 \%$ petani menyatakan usahatani bawang merah kurang menguntungkan karena menganggap ada beberapa komponen biaya yang dikeluarkan dalam jumlah besar, seperti pengendalian hama dan penyakit.

d). Aspek kesesuaian sosial, budaya dan lingkungan

Aspek lain yang diperhatikan dalam mengenalkan suatu inovasi atau teknologi baru adalah kesesuaian terhadap nilai sosial budaya dan kepercayaan petani. Juga tidak bertentangan dengan nilai-nilai konservasi lingkungan setempat.

Hasil evaluasi menunjukkan bahwa sebagian besar petani (67\%) menyatakan kurang sesuai dengan kondisi sosial, budaya dan lingkungan. Kesesuaian dengan aspek sosial dan budaya tidak dipermasalahkan. Faktor yang paling menjadi pertimbangan untuk menilai adalah kurangnya keyakinan petani tentang kesesuaian lingkungan biologis dan geografis Desa Batu Ampar untuk dikembangkan tanaman bawang merah. Hal ini didasari oleh belum adanya penelitian sebelumnya yang menyatakan bahwa tanaman bawang merah cocok dikembangkan di Desa Batu Ampar.

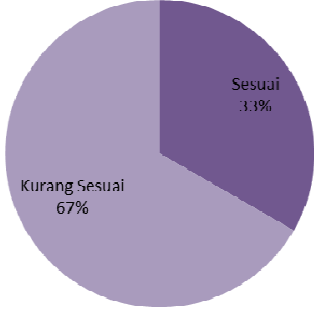

Gambar 6. Persepsi petani tentang kesesuaian sosial, budaya dan lingkungan

Tanaman bawang bawang merah beberapa tahun terakhir mulai dikembangkan oleh masyarakat di Kabupaten Rejang Lebong. Namun kuantitas maupun kualitas produksinya masih belum baik jika dibandingkan dengan daerah lain [5].

e) Aspek keinginan untuk mengadopsi budidaya bawang merah

Tahapan-tahapan yang dilalui oleh masyarakat untuk menerima atau menerapkan suatu teknologi [6]. Tahapantahapan tersebut adalah :

a. Awareness (kesadaran), dimana sasaran mulai sadar tentang adanya inovasi yang ditawarkan.

b. Interest (tumbuhnya minat), umumnya ditandai oleh keinginan untuk bertanya atau untuk mengetahui atau menggali lebih jauh tentang inovasi yang ditawarkan.

c. Evaluation (penilaian), dimana masyarakat sasaran menilai kebaikan atau keburukan serta manfaat inovasi. Aspek yang dinilai meliputi aspek teknis, aspek ekonomi, maupun aspek sosial, budaya, politis atau kesesuaiannya dengan kebijakan pembangunan nasional dan regional. 
d. Trial (mencoba dalam skala kecil), gunanya adalah untuk lebih meyakinkan tentang manfaat inovasi sebelum menerapkannya dalam skala yang lebih besar.

e. Adoption (menerima/menerapkan), penerimaan/penerapan ini dilakukan dengan penuh keyakinan berdasarkan penilaian dan uji coba yang telah dilakukan/diamatinya sendiri.

Hasil evaluasi kegiatan pengenalan teknologi budidaya bawang merah menunjukkan bahwa hanya sebagian kecil petani peserta kegiatan yang menyatakan ingin mengadopsi (44\%), sementara sisanya $(56 \%)$ menyatakan kurang ingin mengadopsi (Gambar 7).

Hal ini mungkin disebabkan karena para petani peserta baru diperkenalkan teknologi budidaya bawang merah dalam kegiatan ini. Tahapan yang baru dilalui hanya sampai tahap Evaluation (menilai). Kegiatan ini belum sampai melibatkan petani dalam kegiatan tahap Trial (mencoba dalam skala kecil), sehingga petani belum yakin sepenuhnya untuk mau mengadopsi teknologi yang dikenalkan.

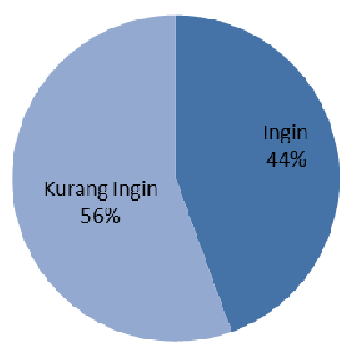

Gambar 7. Keinginan petani untuk mengadopsi dan meneruskan pengetahuannya
Beberapa hal lain juga harus dipertimbangkan lebih lanjut sebelum petani meyakini untuk menerima inovasi tertentu. Upaya lain mungkin mempengaruhi adalah menanamkan keyakinan petani akan kesesuaian lahan di Desa Batu Ampar untuk ditanami bawang merah.

f). Persepsi petani terhadap budidaya bawang merah secara keseluruhan

Berdasarkan semua aspek secara keseluruhan, dapat dijelaskan bahwa umumnya petani (67\%) memberikan persepsi atau pandangan yang baik terhadap budidaya tanaman bawang merah, sisanya (33\%) menyatakan kurang baik (Gambar 8). Walau sebagian besar masih belum ingin mengadopsi teknologi bawang merah. Namun berdasarkan banyak aspek, sebagian besar petani berpandangan baik terhadap teknologi budidaya bawang merah yang diperkenalkan.

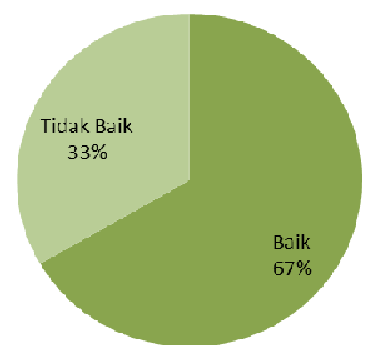

Gambar 8. Persepsi Petani terhadap Budidaya Bawang Merah secara Keseluruhan

Persepsi yang baik, dapat saja menjadi dasar untuk selanjutnya petani mau mengadopsi. Agar petani mau mengadopsi, maka perlu diperkenalkan lebih jauh tentang budidaya bawang merah dengan 
cara mengamati langsung ke lahan bawang merah di kecamatan-kecamatan lain yang sudah lebih dulu menanam bawang merah. Upaya lain yang bisa dilakukan adalah membuat lahan-lahan percontohan agar petani dapat langsung mengamati dan bahkan mencoba langsung.

Petani juga harus dibekali pengetahuan-pengetahuan praktis lainnya yang menjamin keberhasilan budidaya. Misalnya tentang pemilihan varietas yang tinggi produktifitasnya maupun yang menguntungkan secara ekonomis. Varietas-varietas bawang merah yang selama ini dikembangkan di Kabupaten Rejang Lebong yang berbatasan dengan Kabupaten Kepahiang adalah varietas Selupu Rejang, Batu Ijo dan Maja Cipanas. Varietas Selupu Merah memiliki produktivitas paling tinggi dibanding varietas Batu Ijo dan Maja Cipanas, berturut-turut sebesar 24,47 ton/ha, 22,30 ton/ha dan 14,07 ton/ha. Namun secara ekonomis varietas Maja Cipanas lebih menguntungkan, dimana RC Ratio usahatani varietas Maja Cipanas sebesar 2,81, sementara varietas Batu Ijo dan Selupu Merah memiliki RC Ratio sebesar 1,85 dan 1,49 [6]. Hasil-hasil penelitian seperti ini juga dapat menjadi pertimbangan bagi petani untuk memulai mengadopsi suatu teknologi.

\section{KESIMPULAN}

a) Petani peserta sangat antusias mengikuti kegiatan pengenalan budidaya tanaman bawang merah, baik saat pemaparan materi maupun pengamatan di lapangan, maupun memberikan evaluasi terhadap materi yang diberikan. Beberapa cara budidaya bawang merah dibahas dalam sesi diskusi.

b) Hasil evaluasi kegiatan menunjukkan bahwa sebagian besar petani memberikan persepsi yang baik terhadap teknologi budidaya bawang merah yang diperkenalkan.

\section{SARAN}

Sebaiknya petani diperkenal secara lebih mendalam pengetahuan tentang budidaya bawang terutama pengenalan dan pengendalian hama dengan cara mempraktekkan langsung, agar petani lebih yakin dan mau mengadopsi teknologi yang diberikan.

\section{UCAPAN TERIMAKASIH}

Ucapan terimakasih disampaikan kepada Kepala Desa Batu Ampar, Penyuluh Pertanian Lapangan Desa Batu Ampar, para petani dan seluruh masyarakat Desa Batu Ampar Kecamatan Merigi Kabupaten Kepahiang Provinsi Bengkulu.

\section{REFERENSI}

[1] Marlin, M., Sitorus, A., Solihin, M., Romeida, A., dan Herawati, R. 2020. Pemberdayaan Masyarakat Pesantren Ar-Rahmah Rejang Lebong dalam Memanfaatkan Lahan Pekarangan dengan Budidaya Bawang Merah. Jurnal Agrokreatif. 6 (1): 53-61

[2] Kementerian Pertanian RI. 2018.

$\begin{array}{lcr}\text { Keputusan } & \text { Menteri } & \text { Pertanian } \\ \text { Republik } & \text { Indonesia } & \text { Nomor: } \\ \text { 472/Kpts/RC. } & \text { 040/6/2018. } & \text { Tentang }\end{array}$

http://logista.fateta.unand.ac.id 
Lokasi Kawasan Pertanian Nasional.

[3] Moekasan, T.K., dan Basuki, R.S. 2007. Status Resistensi Spodoptera exigua Hubn. pada Tanaman Bawang Merah Asal Kabupaten Cirebon, Brebes, dan Tegal Terhadap Insektisida yang Umum Digunakan Petani di Daerah Tersebut. Jurnal Hortikultura. 17(4): 21-24

[3] Halil, W., dan Armiati. 2018. Kriteria Pemilihan Inovasi Pertanian untuk Mempercepat Proses Adopsi dan Difusinya kepada Pengguna. Balai Pengkajian Teknologi Pertanian Sulawesi Selatan. http://sulsel.litbang. pertanian.go.id. Diakses Tanggal 30 Maret 2020 Pukul 14.30 WIB

[4] Muhamad, N. 2018. Empat Kecamatan Jadi Lokasi Pengembangan Tanaman
Bawang. https://bengkulu.antaranews. com. Diakses Tanggal 30 Maret 2020 Pukul 13.35 WIB

[5] Sasongko, W.A., Witjaksono, R., dan Harsoyo. 2014. Pengaruh Perilaku Komunikasi terhadap Sikap dan Adopsi Teknologi Budidaya Bawang Merah di Lahan Pasir Pantai Kecamatan Sanden Kabupaten Bantul. Agro Ekonomi. 24(1):35-43

[6] Oktavia, Y., Yartiwi., dan Damiri, A. 2019. Keragaan Pertumbuhan dan Tingkat Kelayakan Usaha Tani Tiga Varietas Bawang Merah : Studi Kasus di Kecamatan Selupu Rejang Kabupaten Rejang Lebong Provinsi Bengkulu. Jurnal Ilmu-ilmu Pertanian Indonesia. 21(2):103-107 